\title{
パルプサスペンションの流動への化学エ学的アプローチ
}

\author{
東京工業大学工学部化学工学科 小川 浩平, 吉川 史郎, 小川 博久
}

\section{Chemical engineering approach to pulp-suspension flow}

\author{
Kohei Ogawa, Shiro Yoshikawa and Hirohisa Ogawa \\ Department of Chemical Engineering Tokyo Institute of Technology
}

\begin{abstract}
An experimental investigation of a pulp-suspension flow in a circular pipe was made. The pressure loss was measured by using pressure transducers, and the velocity gradient at pipe wall and the local velocity were measured by an electrochemical technique. The local pulp-fiber concentration was also directly measured by sampling the pulp-suspension flowing in a circular pipe.

Flow characteristics of pulp-suspension was examined from the lower flow region of the relation between pressure loss and flow rate. The relationship between friction facter and Reynolds number was examined. Though there were inconsistencies between the flow characteristics and the relationship between friction facter and Reynolds number, the inconsistencies were explained by considering the mechanism of pulp-suspension flow on the measured pulp-fiber concentration distribution and the measured velocity distribution and so on. And a model for the lower flow region of under one-percent concentrated pulp-suspension was presented.
\end{abstract}

はじめに

製紙産業は装置産業である。一方，化学工学という 学問分野は装置内の運動量移動, 物質移動, 反応そし てエネルギー移動を明らかにし, 装置の最適設計・改 良あるいは最適操業条件に指針を与える学問分野であ る。したがって，製紙産業と化学工学との間には自ず と強い結びうきがあって当然のことと思われる。しか しながらこれまでのところ両者の結びつきはきわめ て希薄であったと言っても過言ではない。

そのことはパルプサスペンションの流動の問題にお いても例外ではなく，以下のような形でみられる。た とえば，パルプサスペンションが円管内を流動する際 の管摩擦抵抗は, 現在でも圧力損失と流量の関係で考 えられており ${ }^{1), 4}$, スケールアップのことを念頭におい た管摩擦係数とレイノルズ数の関係 (無次元数の関係) で扱われたことはほとんどない。したがって，化学工 学における手法を用いてパルプサスペンションの流動 を解析することにより, 従来不明であった点を明らか にしたり，新たな問題点を指摘できる可能性がある。 そこでここで特にパルプサスペンションの円管内流動 に焦点を絞って化学工学的なアプローチを試みた結果 について述べる。

\section{1. 実験}

\section{1 実験 装置}

パルプサスペンションが鉛直管内を流れる際の圧力 損失, 流量, 局所流速, 壁面における速度勾配, 局所 パルプ繊維濃度を測定することによりパルプサスペン ションの円管内流動に関する実験的検討を行った。

実験に用いた装置は図 1 に示したもので，パルプサ スペンションは上部タンクより助走区間を通ってテス トセクションを流下する。流量の調節はテストセク ションの下流に設置したバルブによって行った。実験 に用いた円管は $1 \%$ \%下のパルプサスペンションに対 しては内径 $25 \mathrm{~mm}$ のアクリル樹脂管であり, 1 3\%の 試料に対しては $50 \mathrm{~mm}$ のアクリル樹脂管である。

図2はテストセクションを拡大した図である。圧力 損失は管軸方向の 2 点間の圧力差を動ひずみ測定器 (共和電業製)を用いて測定することにより求めた。流 量は重量法により直接測定した。

局所流速及び壁面速度勾配は電極反応法6),7),8 定した。パルプサスペンションの母夜である水にフェ ロシアン化カリウム $\left(\mathrm{K}_{4}\left[\mathrm{Fe}(\mathrm{CN})_{6}\right]\right)$, フェリシアン化 カリウム $\left(\mathrm{K}_{3}\left[\mathrm{Fe}(\mathrm{CN})_{6}\right]\right)$ を各々 $3 \times 10^{-3} \mathrm{~mol} / l$, 支持 電解質として塩化カリウム $(\mathrm{KCl}) 0.1 \mathrm{~mol} / l$ を溶解さ 

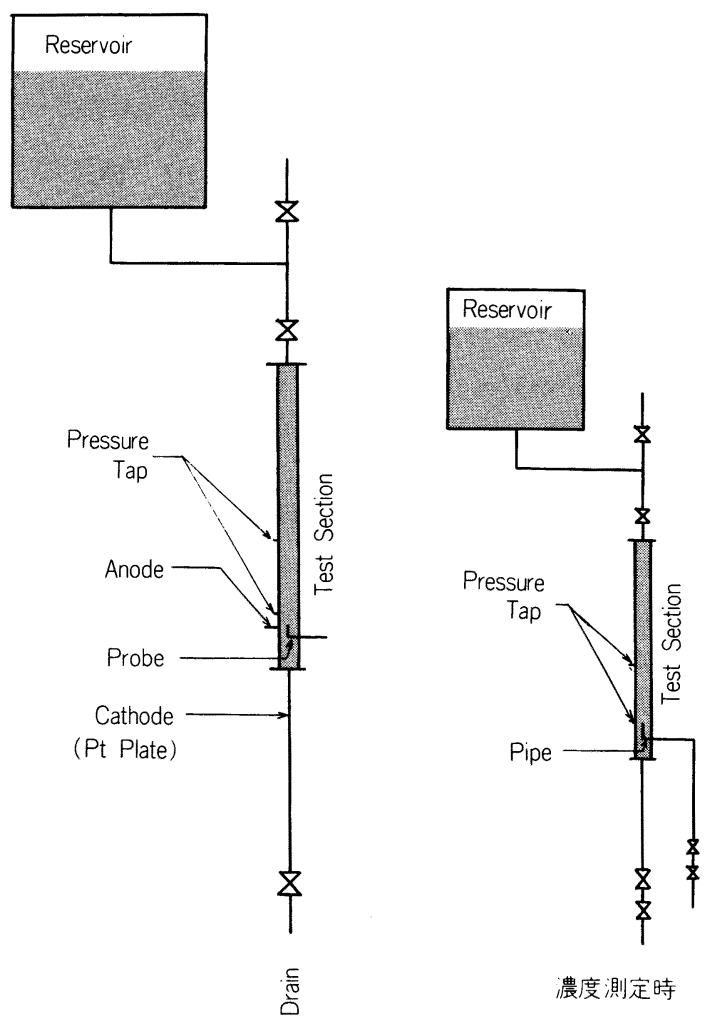

流速測定時

図 1 実験装 置

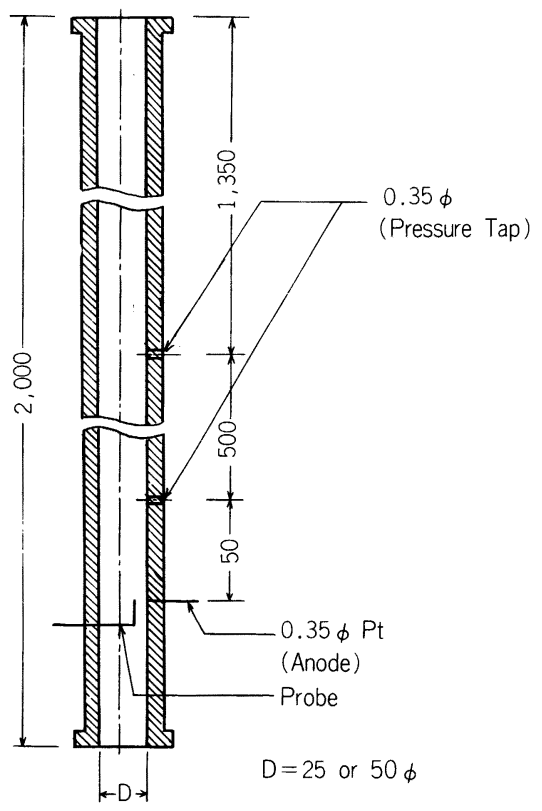

図 2 テストセクション

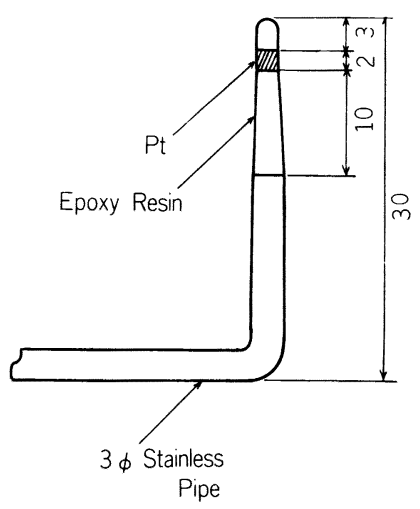

図 3 流速測定用プローブ

せ，流速測定用プローブあるいは壁面速度勾配測定用 プローブ (正極) とテストセクションより下流に設け た白金板（負極）との間に生じさせた電気分解を利用 して測定した。局所流速を測定したプローブは図 3 に 示したようなブラントノーズを有するもので，図中の 矢印の方向からパルプサスペンションが流れてくるた め電極表面にパルプ繊維が付着する恐れは極めて少な い。壁面測定用プローブは白金線をパイプに埋め込み その表面は管壁と同一面になるようにしてある。

局所濃度の測定は図 1 の右図のように局所流速測定 用のプローブの代わりに細い内管をその管軸がテスト セクションの管軸と平行になるように配置し，そのパ イプに流れ込んでくるパルプサスペンションを採取し て濃度を直接求めた。

局所流速測定用プローブ，濃度を測定するときに用 いる細い円管とも管半径方向の数点にトラバースして, 流速分布および濃度分布を求めた。

\section{2 試 験流体}

使用したパルプサスペンションはLBKPをビー ターで吒解しイオン交換水に悡濁させたものである。 パルプ緘維濃度は $0.1 〜 3 \%$ 間にあり，フリーネスは 230 $470 \mathrm{~m} l$ の間にある。また, 電極反応を利用して局 所流速や壁面速度勾配を測定するために先に述べた量 だけ母液である水にフェロシアン化カリウム $\left(\mathrm{K}_{4}[\mathrm{Fe}\right.$ $\left.\left.(\mathrm{CN})_{6}\right]\right)$, フェリシアン化カリウム $\left(\mathrm{K}_{3}\left[\mathrm{Fe}(\mathrm{CN})_{6}\right]\right)$, 支持電解質として塩化カリウム $(\mathrm{KCl})$ を溶解させてあ る。

\section{2. 圧力損失と流量の関係}

図 4 は 1\%以下のパルプサスペンションの圧力損失 


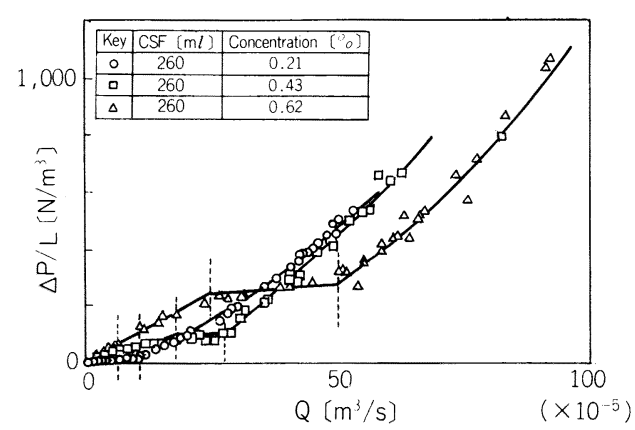

図 4 1\%以下のパルプサスペンションの圧力損 失と流量の関係

と流量の関係 7 (1)8 である。この図より $1 \%$ 以下のパルプ サスペンションの圧力損失と流量の関係は以下の 3 つ の部分からなっていることが分かる。流量の小さい側 から,

(1) 圧力損失が流量に比例して増加する部分

(2) 流量の増加にもかかわらず圧力損失がほとんど 増加しない部分

(3) 圧力損失が流量の増加にしたがってかなり急に 増加する部分

である。既往の研究 ${ }^{2)}$ と比較することによりこれらの 部分は流量の小さい側から栓流, 混相流, 乱流におお むね一致していることが分かった。

この圧力損失と流量の関係はパルプ濃度に依存して おり, パルプ濃度が大きくなるにしたがって(1), (2)の 部分は流量の広い範讲にわたり，(1)の部分では直線の 傾きが大きくなっていく傾向にある。また，圧力損失 と流量の関係はフリーネスには影響されない7ことが 分かった。

図 5 は 1 3\%のパルプサスペンションの圧力損失 と流量の関係である。1\%以下のパルプサスペンション

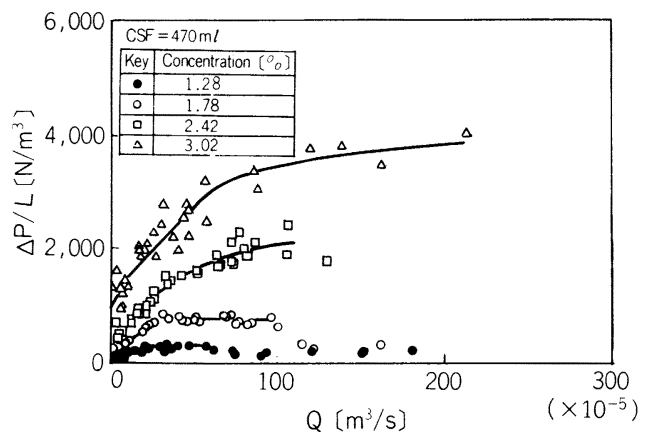

図 5 1 3\%のパルプサスペンションの圧力損失 と流量の関係
の関係とは明確に異なっていることが分かる。測定さ れた範囲内では以下の 3 つの部分が確認される。流量 の小さい側から，

(1) 圧力損失が流量が増加するにつれて直線的に増 加する部分

(2) 流量の増加にもかかわらず圧力損失がほとんど 変化しない部分

(3) 流量が増加するにつれて圧力損失が(2)の部分よ りも小さくなり，しかも減少してゆく部分

である。1〜3\%のパルプサスペンションの圧力損失と 流量の関係では, $1 \%$ 以下のパルプサスペンションの場 合のように(1)の部分は原点を通らない。すなわち(1)の 部分を代表する直線を流量がゼロへ外挿すると流量が ゼロのときに圧力損失が有限の值を持つことになり, ビンガム性を有することが分かる。また, パルプ繊維 濃度への依存性には $1 \%$ 以下のパルプサスペンション の場合と同様の傾向が見られる。

$1 \%$ 以下のパルプサスペンションの圧力損失と流量 の関係には，1〜3\%のパルプサスペンションの圧力損 失と流量の関係で見られる(3)のよな部分が見られな い。しかし, この事実は $1 \%$ 以下のパルプサスペンショ ンが 1 〜\%のパルプサスペンションと, 圧力損失と流 量の関係において異なることを表わしているのではな いと思われる。既往の研究2)も参考にして考察した結 果, $1 \%$ 以下のパルプサスペンションの圧力損失と流量 の関係においては，そのような部分は存在するのが非 常に狭い範囲のために図中に明確に現われないと思わ れる。

この圧力損失が流量の増加にもかかわらず減少して ゆく部分に対しては定性的にではあるが次のような考 察を行った。既往の研究2)よりこの部分では, パルプ繊 維が絡まり合ってできたネットワークが存在し, その ネットワークと管壁との間に層流で流れる水環が存在 する。また，この水環は流量が増加するにつれてその 厚みを増してゆく。一般に圧力損失は管壁における剪 断応力を用いて

$$
\Delta \mathrm{P}=\frac{2 \mathrm{~L}}{\mathrm{R}} \tau_{\mathrm{w}}
$$

で表わされる。また, 一般に剪断応力は剪断速度と粘 度を用いて

$$
\tau_{\mathrm{w}}=\left.\mu\left(-\frac{\mathrm{du}}{\mathrm{dr}}\right)\right|_{\mathrm{r}=\mathrm{R}}
$$

で表わされる。したがって，圧力損失は管壁における 流体の粘度と剪断速度の積に比例する。いま問題にし ている部分よりも流量の小さい部分では水とパルプ緎 維がいずれも管壁と接触している。したがって, 管壁 
における剪断応力は，水と管壁およびパルプ纎維と管 壁の接触により生じていると考えられる。一方，圧力 損失が流量の増加にもかかわらず減少していく部分で は，上述したように水環が存在するために管壁におけ る剪断応力は水と管壁の接触によってのみ生じている と考えられる。均質流体の場合は流量が増加するにつ れて管壁における剪断速度は大きくなるが，水の粘度 と比べて相当に大きい粘度を有すると考えられるパル プサスペンションの場合は流量が増加するにつれて管 壁における剪断速度が増加しても，管壁は水環で覆わ れるようになって粘度が当初より小さくなるために結 果として圧力損失は小さくなると考えられる。また, 管壁付近の水環は流量の増加につれてその厚みを増し て行くことが報告されており，そのために流量が増加 するにもかかわらず管壁における剪断速度が小さくな り, 結果として圧力損失は滅少してゆくと推察される。

\section{3. パルプサスペンションの流動特性}

流体の挙動を調べるとき，その流体の流動特性は重 要な基本要素である。水や空気などの均質（単一相と いうだけでなく，管内の全域にわたって均質である) な流体に対しては円管内を層流で流れる際の圧力損失 と流量を測定することで，その流動特性を決定するこ とが可能である ${ }^{8)}$ 。

ところで，パルプサスペンションは空気の相を無視 すると，パルプ纎維と水の混合物と考えられる。した がって，パルプサスペンションが速度勾配を有して流 れる場合には速度の異なる流体層の間で, 水一水, 水 一パルプ㵶維, パルプ纎維—パルプ繊維の間での内 部摩擦が生じていると思われる。そこで，パルプサス ペンションをこれらの内部摩擦によるのと正味同じ内 部摩擦（粘性）を生じる均質流体として捉えて扱うこ とを試みだ。

パルプサスペンションの流動特性は, 圧力損失と流 量の関係における流量の小さい部分，すなわち $1 \%$ 以

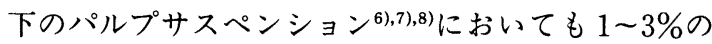
パルプサスペンションにおいても(1)の部分を用いて決 定した。(この部分では流体は半径方向の速度成分を有 せず，管軸方向の速度成分のみを有している，すなわ ち層流で流れていると思われる。この部分は従来から 知られている圧力損失と流量の定性的な関係 (図 64) 参照）におけるCの流域までに対応する。

1\%以下のパルプサスペンションに対する結果は図 7 に示すようなものであり, 流動特性は原点を通る直 線で近似することができる。つまり，ニュートン流体 と考えられる。一方，1３\%の範囲のパルプサスペン

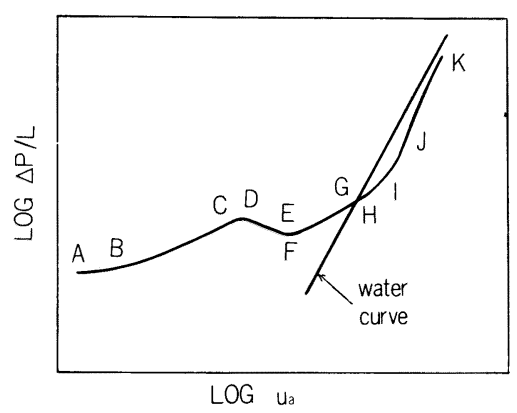

図 6 圧力損失と流量の関係 $(\log \Delta \mathrm{P} / \mathrm{L}$ vs $\log$ $u_{a}$ )

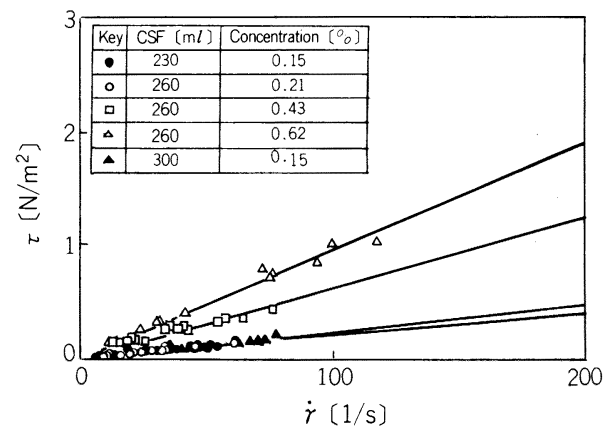

図 7 1\%以下のパルプサスペンションの流動特性

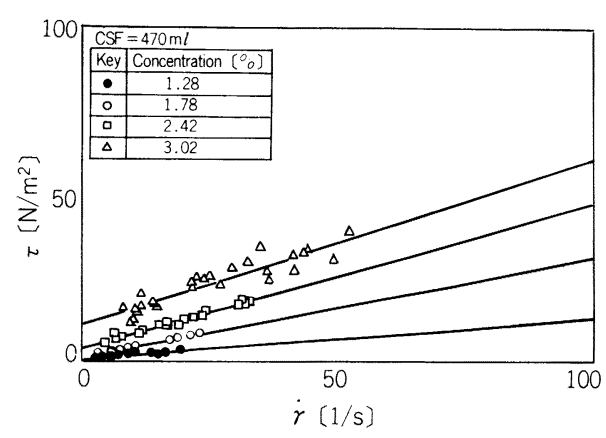

図 8 1 3\%のパルプサスペンションの流動特性

ションに対する結果は図 8 に示すように, 原点を通ら ずにY切片をも直線で近似される。つまり，ビンガ ム流体と考えられる。表 1, 2 は各パルプサスペンショ ンに対して求めた粘度および降伏応力である。この表 より $1 \%$ 以下のパルプサスペンションではパルプ濃度 の増加とともに粘度が増加することが認められる。ま た, 1 3\%のパルプサスペンションの場合には, 降伏 応力およびビンガム粘度 (図中の直線の傾き) が同様 にパルプ濃度の増加とともに大きくなっている。先に, パルプサスペンションを水一水, 水一パルプ䋐維, 
表 1 1\% 以下のパルプサスペンションの見かけ 粘度

\begin{tabular}{c|c|c|c|c|c}
\hline $\begin{array}{c}\text { Concentration [\%] } \\
\text { CSF }[\mathrm{m} l]\end{array}$ & $\begin{array}{c}0.15 \\
230\end{array}$ & $\begin{array}{c}0.21 \\
260\end{array}$ & $\begin{array}{c}0.43 \\
260\end{array}$ & $\begin{array}{c}0.62 \\
260\end{array}$ & $\begin{array}{c}0.15 \\
300\end{array}$ \\
\hline$\mu_{\mathrm{a}} \times 10^{3}[\mathrm{~kg} /(\mathrm{m} \cdot \mathrm{s})]$ & 2.40 & 2.51 & 6.36 & 9.70 & 2.11 \\
\hline
\end{tabular}

表 2 1 3\%のパルプサスペンションの降伏応力 とビンガム粘度

\begin{tabular}{c|c|c|c|c}
\hline $\begin{array}{c}\text { Concentration [\%] } \\
\text { CSF }[\mathrm{m} l]\end{array}$ & 1.28 & 1.78 & 2.42 & 3.02 \\
\hline$\tau_{\mathrm{B}}\left[\mathrm{N} / \mathrm{m}^{2}\right]$ & 0.552 & 1.19 & 3.39 & 11.5 \\
$\mu_{\mathrm{B}} \times 10[\mathrm{~kg} /(\mathrm{m} \cdot \mathrm{s})]$ & 1.23 & 3.04 & 4.43 & 4.94 \\
\hline
\end{tabular}

パルプ繊維—パルプ緘維の間の接触により生じる内 部摩擦と正味同じ内部摩擦を生じる均質流体と考える ことにすると述べたが，これらの内部摩擦を生じる機 構の中でパルプ繊維一パルプ繊維の接触により生じ る内部摩擦が他の内部摩擦よりも大きく, パルプ緘維 の濃度が大きくなるとパルプ繊維—パルプ繊維の接 触の度合が水一水，水一パルプ緎維の接触の度合よ りも増えてゆき, その結果, 全体の内部摩擦が増加し 粘度や降伏応力が大きくなっていくと思われる。

\section{4. 管摩擦係数とレイノルズ数の関係}

パルプサスペンションは水とパルプ敉維の混合物と 考えられるが，静止したパルプサスペンション中にお いて，パルプ纎維はそれぞれ独立に存在しているので はなく，お互いに絡まり合った状態にある。そのため， 応力に対する抵抗が生じ, 応力がある有限値に達した ときに流動が起こると考えられる。このことから，パ ルプサスペンションの流動特性には元来降伏応力が存 在しているものと思われる。しかし，化学工学におい ては非ニュートン流体に比べてニュートン流体の取扱 いが進んでおり，しかも容易である。そこで，化学工 学的な取扱いの観点から, パルプ濃度が小さく降伏応 力が無視できる範囲では, パルプサスペンションを ニュートン流体とみなすことにする。(いまのところ降 伏応力が無視できるパルプ繊維濃度の範囲は 0.6 ～1\% の間にある可能性だけが予測されるが，それが何\%で あるか正確なことは不明である。）

流体が円管内を流れる場合の圧力損失の問題は，又 ケール・アップを念頭において流れの相似条件をもと に，管摩擦係数とレイノルズ数の関係で取り扱われる。 その際にレイノルズ数の中の粘度の項は当然のことな
がらパルプサスペンションが円管内を流れるときの流 体の粘度を用いなければならない。過去においては， パルプサスペンションの粘度として母液の水の粘度を 用いて検討した例 ${ }^{3), 4}$ があるが明確な結果は得られて いない。そこで，先に決定したパルプサスペンション の流動特性を利用して，圧力損失の問題を管摩擦係数 とレイノルズ数の関係を検討してみた。

1\%以下のパルプサスペンションはニュートン流体 とみなせるので, 管摩擦係数とレイノルズ数 ${ }^{7), 81}$ は

$$
\mathrm{f}=\left(\frac{\Delta \mathrm{P}}{2 \rho \mathrm{u}_{\mathrm{a}}}\right)\left(\frac{\mathrm{D}}{\mathrm{L}}\right), \quad \mathrm{Re}=\frac{\rho \mathrm{Du}_{\mathrm{a}}}{\mu}
$$

と書ける。図 9 は管摩擦係数とレイノルズ数の関係で ある。困中の破線はレイノルズ数の小さい側からそれ ぞれ，(1)と(2)の部分の境界，(2)と(3)の部分の境界を示 す。なお以下では，(1)の部分ではパルプサスペンショ ンは管軸方向の速度成分のみを有し，その他の速度成 分は存在しないと思われるので, (1)の部分を層流域と 呼ぶことにする。一方，(3の部分は水やパルプ繊維が 乱流状態で流れているので，(3)部分を乱流域と呼ぶ ことにする。また，(2)の部分は(1)と(3)の部分の中間に あるので遷移域と呼ぶことにする。困より，層流域で は $\mathrm{f}=16 / \operatorname{Re}$ の関係を，管摩擦係数とレイノルズ数の 関係は十分に満たしていることが分かる。一方，乱流 域においてはニュートン流体が満たす Blasius の関係 から外れる傾向にある。その外れる度合はパルプ濃度 が增加するにつれて大きくなっている。この Blasius の関係から外れることに関しては後で考察を加えるこ とにする。

1 3\%のパルプサスペンションはビンガム流体とみ なせた。しかし，残念ながら現状では非ニュートン流 体に対してはニュートン流体の場合と異なり，一般的 な管摩擦係数とレイノルズ数の関係は見つかっていな

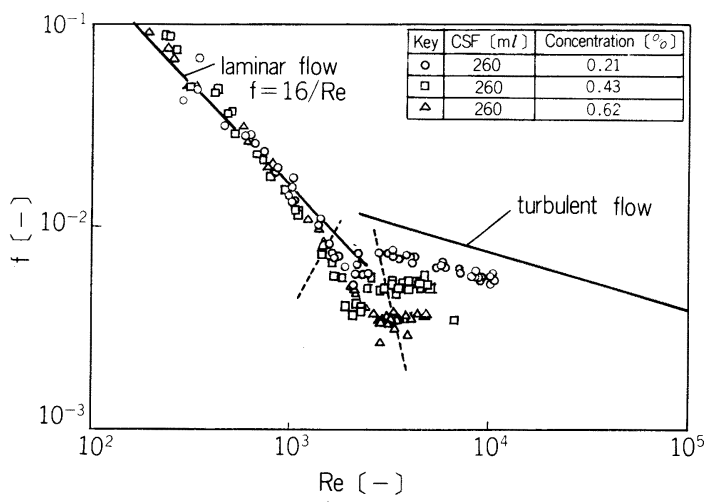

図 9 1\%以下のパルプサスペンションの管摩擦 係数とレイノルズ数の関係 
い。すなわち，非ニュートン流体に対する適当なレイ ノルズ数が見つかっていない。そこで，一つの試みと して, エネルギー散逸の相似則を利用してまとめるこ とを試みた。このエネルギー散逸の相似則5)の詳細な 説明はここでは省略するが，概略は以下のようなもの である。流体内にある領域を考え，その領域に対する エネルギー収支を出発点としたものであり, 非ニュー トン流体の圧力損失と流量の関係と Hagen-Poiseuilleの式を比較し, ニュートン流体の粘度の項にあた る項を非ニュートン流体の粘度の項として見かけ粘度 と呼び, この粘度をレイノルズ数の粘度の項として用 いる。例えば，ビンガム流体に対する見かけ粘度とレ イノルズ数はビンガム流体が層流で流れるときの栓半 径を $\mathrm{a}, \alpha$ を $\alpha$ 関数とするとき

$$
\mu_{\mathrm{a}}=\frac{\mu_{\mathrm{B}}}{4 \mathrm{a} \alpha}, \quad \operatorname{Re}=\frac{\rho \mathrm{Du}_{\mathrm{a}}}{\mu_{\mathrm{a}}}
$$

となる。このようなレイノルズ数を用いて圧力損失の データを管摩擦係数とレイノルズ数の関係にまとめる と, 当然のことながら層流域においては $\mathrm{f}=16 / \operatorname{Re} の$ 関係を満たす。そこでさらに管摩擦係数とレイノルズ 数に運動エネルギーの補正を行い, 乱流域のデー夕も ニュートン流体の乱流域の関係を満たすようにする。 したがって，エネルギー散逸の相似則を利用すれば, 非ニュートン流体の圧力損失のデー夕を遷移域を除い てニュートン流体の管摩擦係数とレイノルズ数の関係 と同様にまとめることができるわけである。

図 10 はエネルギー散逸の相似則を利用してまとめ た 1 3\%のパルプサスペンションの管摩擦係数とレ イノルズ数の関係である。管摩擦係数とレイノルズ数

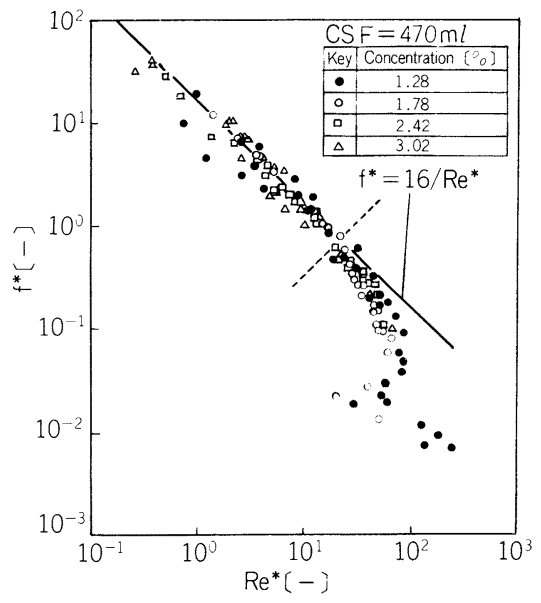

図 10 1 3\%のパルプサスペンションの管摩擦係 数とレイノルズ数の関係
には先に述べたものに，運動エネルギーの補正を施し た管摩擦係数とレイノルズ数

$$
\mathrm{f}^{*}=\frac{\mathrm{f}}{\xi}, \quad \operatorname{Re}^{*}=\frac{\rho \mathrm{Du}_{\mathrm{a}} \xi}{\mu_{\mathrm{a}}}
$$

を用いた。ここで, $\xi$ は運動エネルギーの補正係数であ る。図よりレイノルズ数の大きい範囲, すなわち乱流 域のデー夕は得られていないが, (2)と(3)の部分は遷移 域に含まれている。(1)部分は層流域であり, 図中の 破線は層流域と遷移域の境界を表わす。この図より層 流域では概ね $\mathrm{f}^{*}=16 / \mathrm{Re}^{*}$ の関係を満たしている。遷 移域の初期には $1 \%$ 以下のパルプサスペンションでは 見られなかった傾向が存在すると思われるが, 現状で は十分な考察を加えるにはデー夕数が不足している。 今後, 遷移域から乱流域にわたる測定を行い検討をす る必要性がある。

ここまで $1 \%$ 以下, 1 3\%のパルプサスペンション の管摩擦係数とレイノルズ数の関係を別個に見てきた が, 化学工学的アプローチによりかなり定量的に明確 な関係が得られることが分かった。

さて, $1 \%$ 以下のパルプサスペンションはニュートン 流体とみなせた。しかし, 乱流域の初期において管摩 擦係数とレイノルズ数の関係はニュートン流体の関係 にしたがっていない。この矛盾に関して考察をする。

図 11 は 1\%以下のパルプサスペンションの管壁にお ける剪断応力と剪断速度の関係である。各パルプサス ペンションのデータは原点を通る直線関係を満たす。 このことは, パルプサスペンションがニュートン流体 であることとは矛盾しない。しかし, 各直線の傾きか ら粘度を求め流動特性より決定した粘度と比較すると 両者は一致しない（図 12 参照）。つまり，パルプサス ペンションには二つの粘度が存在することになり, パ ルプサスペンションはニュートン流体ではないという ことになる。図13 は管壁における速度勾配と流量の関 係である。図中の実線はニュートン流体に対して成り

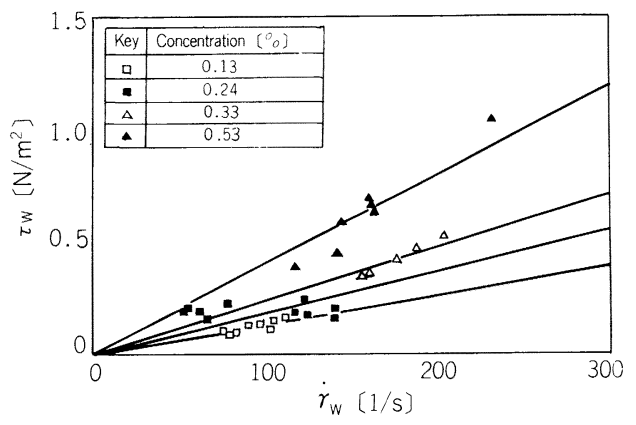

図 11 管壁における剪断応力と剪断速度の関係 
立つ関係

$$
\dot{\gamma}_{\mathrm{w}}=\frac{4}{\pi \mathrm{R}^{3}} \mathrm{Q}
$$

であり，データの多くはこの直線からは大きく偏位し ていることからも，パルプサスペンションはニュート

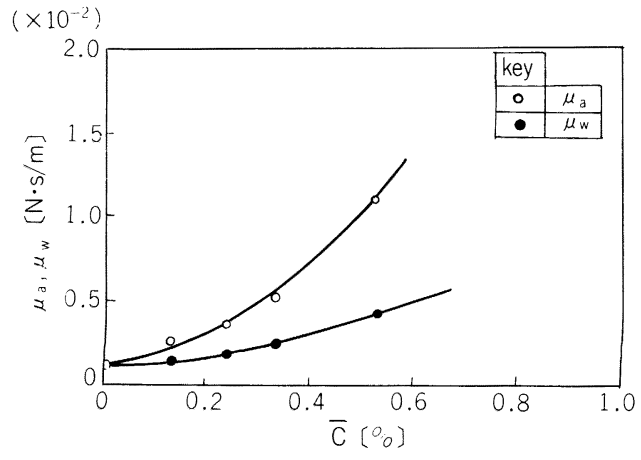

図 12 パルプ繊維濃度に対する見かけ粘度と管壁 における粘度
ン流体ではないことが分かる。

流動特性からはニュートン流体と見なせたにもかか わらず，実はニュートン流体ではないという矛盾を説 明する流動モデル ${ }^{6), 8)}$ を考えることにする。これに先 立って，実測したパルプサスペンションの濃度分布に

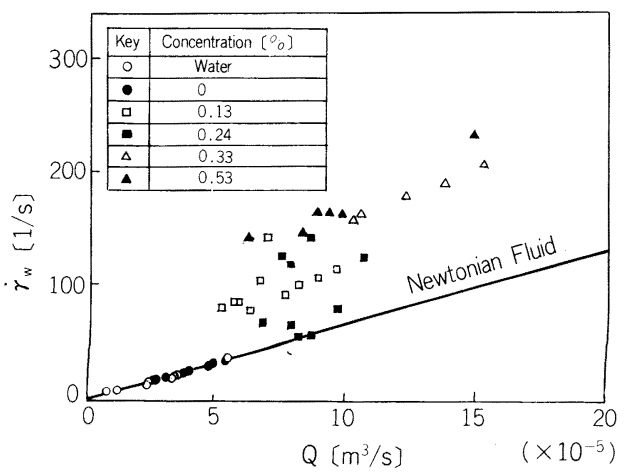

図 13 管壁における剪断速度と流量の関係
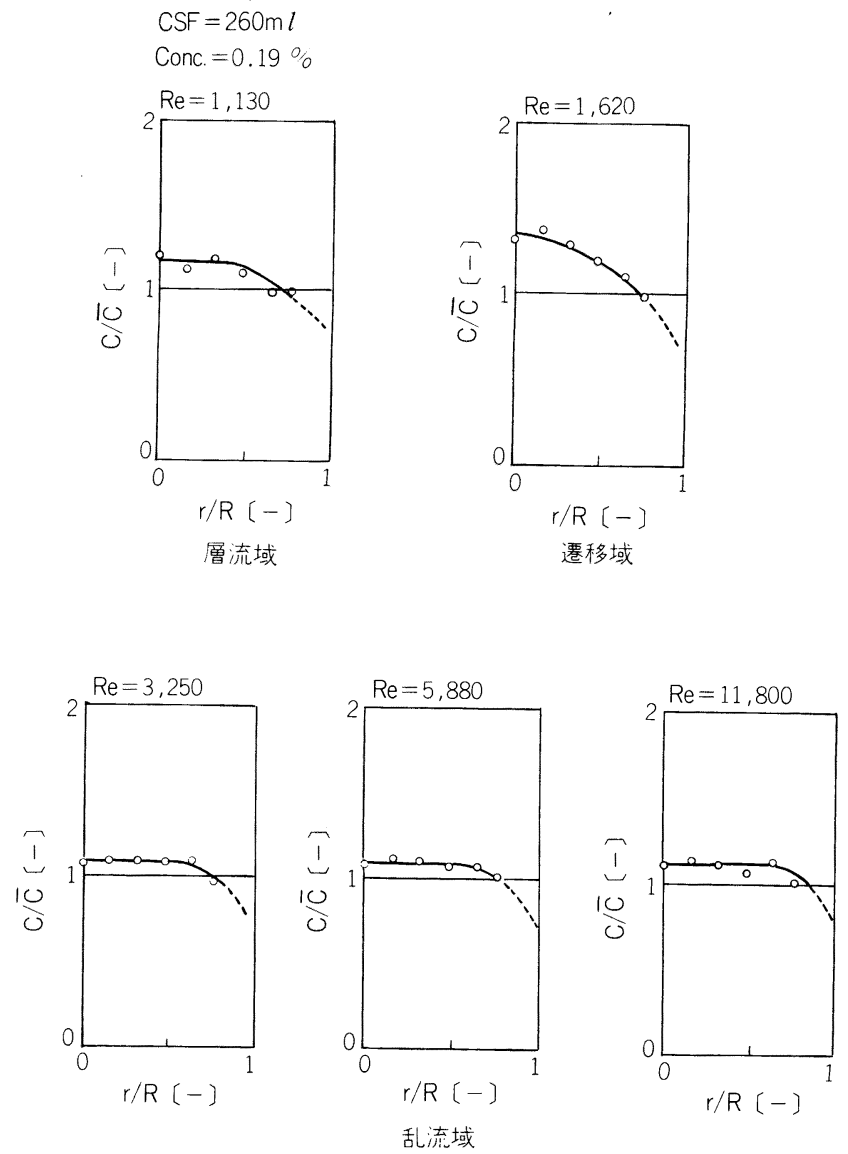

図 $141 \%$ 以下のパルプサスペンションの濃度分布 

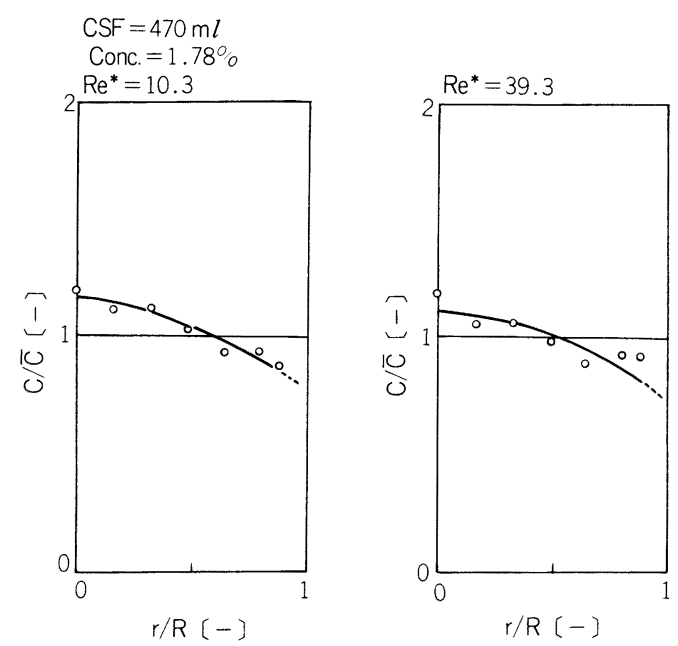

図 151 1 3\%のパルプサスペンションの濃度分布

ついて簡単に触れる。図 14 と図 15 はパルプサスペン ションが円管内を流動しているときの半径方向の濃度 分布である。図 14 は $1 \%$ 以下のパルプサスペンション が円管内を流れているときの濃度分布であり, 図 15 は 1 3\%のパルプサスペンションが流動しているときの 濃度分布である。これらの図より,パルプサスペンショ ンが円管内を流動するときにはパルプ繊維は均質に分 散するのではなく，濃度分布の形に違いこそあれ，ど の濃度分布も管中心付近の方に管壁付近よりもパルプ 繊維がより多く集まっていることが分かる。(このよう な濃度分布が生じる原因としてマグヌス効果, 慣性効 果, パルプ纎維間の相互作用や壁効果などが考えられ るが，これらがどのように効いているかは未だに不明 である。このようにパルブ繊維の濃度分布が半径方向 に存在することを考虑して, 粘度が二つ存在する矛盾 を説明する流動モデルを次のように考えることができ る。

（1）パルプ纎維の半径方向の濃度分布に対応して粘 度も半径方向に分布をもつ。

(2) パルプサスペンションは各半径位置においてそ の位置における粘度の值にもとづいたニュートン 流体として挙動する。

この流動モデルにもとづき，流動特性より決定された 粘度（管内流れの見かけ粘度）と管壁における剪断速 度と剪断応力の関係から求めた粘度（管壁におけるパ ルプサスペンションの粘度）の二つの粘度と管壁にお ける剪断速度の関係は

$$
\dot{\gamma}_{\mathrm{w}}=\frac{4}{\pi \mathrm{R}^{3}} \cdot \frac{\mu_{\mathrm{a}}}{\mu_{\mathrm{w}}} \mathrm{Q}
$$

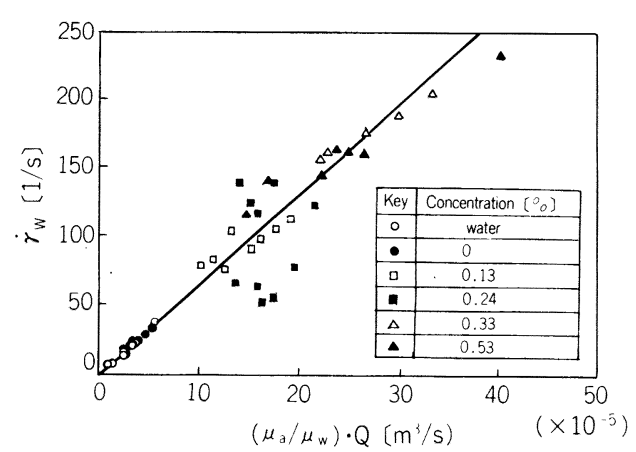

図 16 管壁における剪断速度と $\left(\mu_{\mathrm{a}} / \mu_{\mathrm{w}}\right)$ Q の関係

のよjに表わされる。そこで，各パルプサスペンショ ンに対して求められた $\mu_{\mathrm{a}}$ と $\mu_{\mathrm{w}}$ を用いて $\dot{\gamma}_{\mathrm{w}}$ を $\left(\mu_{\mathrm{a}}\right)$ $\left.\mu_{\mathrm{w}}\right) \mathrm{Q}$ に対してプロットしてみたのが図 16 である。図 中の直線は(7)式を表わしている。この図より，どのパ ルプサスペンションの場合も(7)式の関係を概ね満足し ている。したがって, 上述の流動モデルによって二つ の粘度が存在する矛盾が説明されたことになる。

さて，ここまでパルプサスペンションが円管内を流 動する問題を取り扱ったときに二つの粘度が現われた が, ここでその二つの粘度について考察してみる ${ }^{8)}$ 。粘 度とは元来, 流体の物性であり，ある状態においては， その状態に対して唯一に決まる性質のものである。し たがって, 粘度が二つも存在することは不可解なこと である。流れ場の剪断速度に対する, 流体層の間で生 じている剪断応力の比がパルプサスペンションの粘度 である。先ほど述べた流動モデルの中に“パルプ緘維 の半径方向の濃度分布に対応して粘度も半径方向に分 布をもつ”という仮説があったが，この中で触れられ ている各半径位置における粘度（各半径位置における 濃度をもつパルプサスペンションの粘度）こそ各々の パルプ緘維濃度のパルプサスペンションの粘度である。 したがって，管壁における粘度 $\mu_{\mathrm{w}}$ は, 管壁 (極めて管 壁に近い部分）におけるパルプサスペンションの粘度 でしかない。パルプサスペンションが円管内を層流で 流れるときの圧力損失と流量の関係から求如れた粘 度は物性ではないが, 少なくともパルプサスペンショ ンの流動が反映された管断面についてのある程度の平 均された粘度と考えられる。また，この粘度を用いた レイノルズ数を用いることで, 圧力損失と流量の関係 が上述のような管摩擦係数とレイノルズ数にまとめら れたという点でも有効であると考えられる。

さて，ここまで述べてきたことを踏まえることで, $1 \%$ 以下のパルプサスペンションの管摩擦係数とレイ ノルズ数の関係で, 乱流域の初期において, パルプサ 
スペンションに対するデータがニュートン流体の満た す関係式を満たさないことを説明できるように思われ る。流動特性の上からはニュートン流体とみなせるけ れども，実はパルプサスペンションはニュートン流体 ではなく，パルプサスペンションでは層流域における 流動の機構がニュートン流体のそれと異なっているの と同様に，乱流域においても流動の機構が異なってい るものと考えられる。このように考えると, 圧力損失 と流量の関係から求如れた粘度を用いて，層流域の デー夕をニュートン流体の満たす関係にまとめられた にもかかわらず，乱流域では同じようにまとめられな いことはむしろ当然のこととも考えられる。

以上，パルプサスペンションの円管内流動における

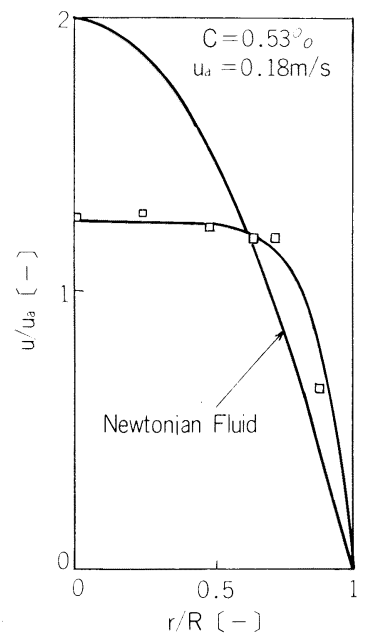

図 17 1\%以下のパルプサスペンションの流速分 布 (層流域)
压力損失の問題について述べてきたが，現時点では層 流域から乱流域まで十分カバーできる一般的な関係は 未だ得られていない。もしかしたら，このパルプ繊維 の管断面内の分散状態を考慮することでよい結果が得 られるかもしれないし，そのことに捕らわれることな く，全く新しい観点からの解析が有効であるかもしれ ない。

\section{5. 流速分布}

図 17 から図 20 は電極反応法を利用して測定した半 径方向の流速分布である。図 17 と図 18 は $1 \%$ 以下の パルプサスペンションの流速分布6),7),8 であり, 図 17 は層流域, 図 18 は乱流域のものである。また, 図 19 と

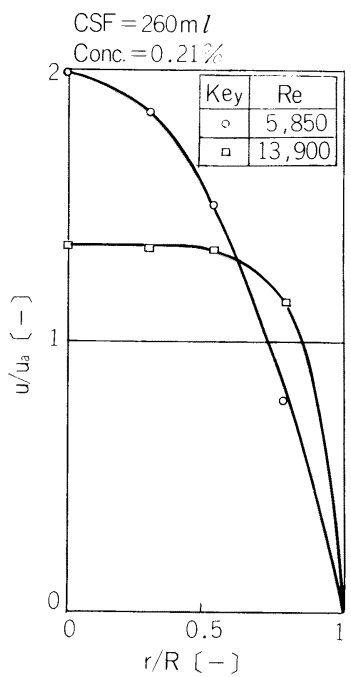

図 18 1\%以下のパルプサスペンションの流速分 布 (乱流域)
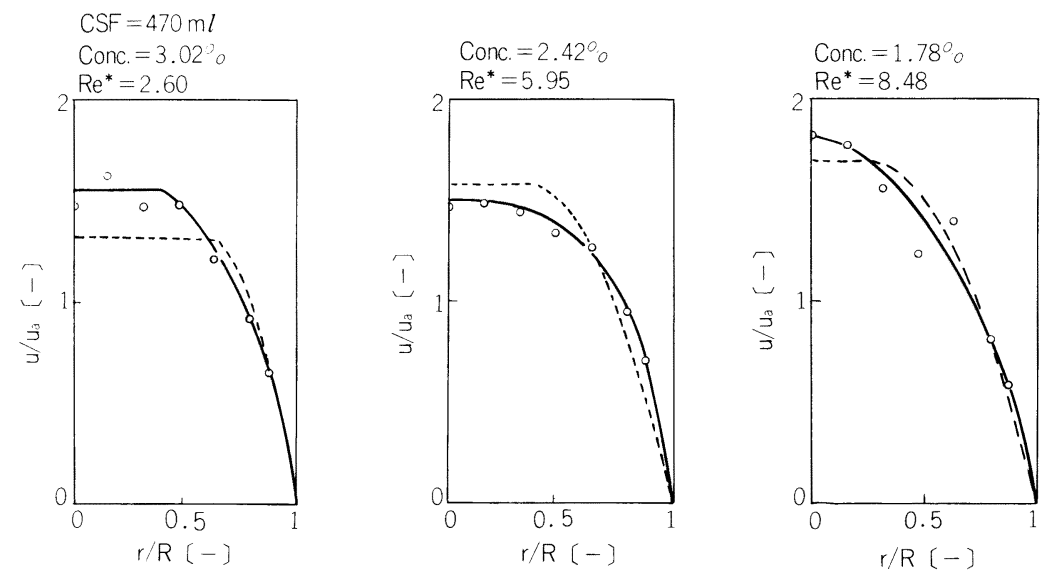

図 19 1 3\%のパルプサスペンションの流速分布（層流域） 

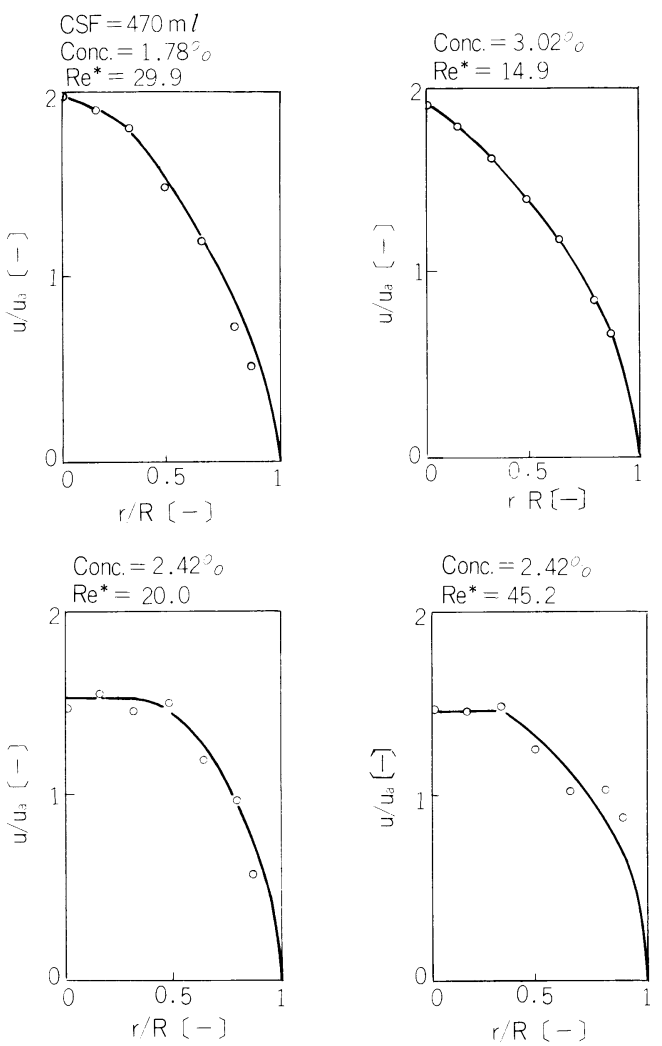

図 20 1 3\%のパルプサスペンションの流速分布 (層流域外)

図 20 は 1 3\%のパルプサスペンションの流速分布で あり，図 19 は層流域，図 20 は層流域外のものである。

図 17 には1\%以下のパルプサスペンションの層流 域の流速分布と一緒に，比較のためにニュートン流体 の層流域の流速分布を載せている。この四より，1\%以 下のパルプサスペンションの層流域の流速分布と ニュートン流体の層流域の流速分布とは大きく異なっ ていることが分かる。このことは，1\%以下のパルプサ スペンションはニュートン流体ではないということと も符合する。

図 19 には1〜3\%のパルプサスペンションの層流域 の流速分布と一緒に，比較のためにパルプサスペン ションの流量と同じ流量でビンガム流体が流れた際の ビンガム流体の流速分布 (破線) を示している。この 図より，1〜3\%のパルプサスペンションの流速分布は， 1\%以下のパルプサスペンションとニュートン流体の 流速分布との違いほどではないにしても，やはりビン ガム流体の流速分布とは異なっている。先に述べたよ うに，1〜3\%のパルプサスペンションも円管内を断面
内にパルプ繊維濃度の分布を有して流れており，均質 なビンガム流体ではない。したがって，流速分有の不 一致はそのことに矛盾することではない。

図 18 は $1 \%$ 以トのパルプサスペンションの乱流域 の流速分布であり，レイノルズ数によって流速分布が 異なることが分かる。ニュートン流体の乱流域の流速 分布は一定の形をしているので, このことは乱流域に おいてもパルプサスペンションの流動のメカニズムは ニュートン流体の流動のメカニズムと罳なることを示 している。また，㭎中の美線は

$$
\frac{\mathrm{u}}{\mathrm{u}_{\mathrm{a}}}=1-\left(\frac{\mathrm{r}}{\mathrm{R}}\right)^{\mathrm{n}}
$$

を表わしており，乱流域の流速分们はこの式でよく表 わされる。

ここまで流速分布の形などを見てきたが，ここで， 1\%以下のパルプサスペンションに注目してその層流 域の流速分布を推定してみる ${ }^{6), 8}$ 。先に $1 \%$ 以下のパル プサスペンションの層流域に対して斿てな流動モデル をもとに，各半径位置におけるパルプサスペンション の粘度を $\mu$ とすると, その半径位置における流速 いは

$$
\dot{\gamma}=\frac{\mathrm{du}}{\mathrm{dr}}=-\frac{\Delta \mathrm{P}}{2 \mu \mathrm{L}} \mathrm{r}
$$

の関係を満たす。この式から流速分存を求めるには粘 度の半径方向の分布が必要である。しかし，パルプサ スペンションの粘度を测定することは現時点では不可 能なので，濃度分布をもとにして半径引们の粘度分布 を求めることはできない。そこで，粘度は壁面で $\mu_{\mathrm{w}}$ に なること，壁面から管中心に台かって単调に增加する こと（濃度分布からこのように\}测される），そして， 管中心付近では非常に大きくなると考えられることを 踏まえて

$$
\mu(\mathrm{r} / \mathrm{R})=\mu_{\mathrm{w}} \cdot \exp \{\mathrm{A}(1-\mathrm{r} / \mathrm{R})\}
$$

のように仮定してみる。ここでAは濃度によって異な るパラメーターである。(10)式を(9)式に代入して䅡分す ると

$$
\begin{aligned}
\mathrm{u}= & -\frac{\Delta \mathrm{PR}^{2}}{2 \mathrm{~A}^{2} \mu_{\mathrm{w}} \mathrm{L}}[\{\mathrm{A}(\mathrm{r} / \mathrm{R})-1\} \cdot \\
& \exp \{-\mathrm{A}(1-\mathrm{r} / \mathrm{R})\}-(1-\mathrm{A})]
\end{aligned}
$$

で表わされる流速分布の式が得られる。この式を用い て流量を求めると

$$
\begin{aligned}
\mathrm{Q}= & \frac{\Delta \mathrm{P} \pi \mathrm{R}^{4}}{\mathrm{~A}^{2} \mu_{\mathrm{w}} \mathrm{L}}\left[-\frac{2}{3}+\frac{3}{\mathrm{~A}}-\frac{3}{\mathrm{~A}^{2}}\right. \\
& \left.\times\{1-\exp (-\mathrm{A})\}+\frac{\mathrm{A}}{2}\right]
\end{aligned}
$$

が得られ，一方，1\%以下のパルプサスペンションの流 動特性のところで求㚲度を刖いると, 厈力損失と 流量の間には 


$$
\mathrm{Q}=\frac{\Delta \mathrm{P} \pi \mathrm{R}^{4}}{8 \mu_{\mathrm{a}} \mathrm{L}}
$$

の関係がある。(12)式と(13)式からパラメーター A は粘度 $\mu_{\mathrm{a}}$ と $\mu_{\mathrm{w}}$ とで

$$
\frac{\mu_{\mathrm{a}}}{\mu_{\mathrm{w}}}=\frac{\mathrm{RL}}{\mathrm{AD}^{2}}\left(1-\frac{1}{\mathrm{~A}}\right)-\frac{\mathrm{L}}{\mathrm{A}^{2} \mathrm{D}^{2}}
$$

のように表わせる。この式に $\mu_{\mathrm{a}}$ と $\mu_{\mathrm{w}}$ を代入すること により $\mathrm{A}$ を決定することができる。この $\mathrm{A}$ と管壁に 㧍ける粘度 $\mu_{\mathrm{w}}$ から半径方向の粘度分布の式が決定さ れ，それを沙尔したのが図21である。四中の直線の傾 きがハララメーターAであり，パラメーターAはパルプ 濃度が濃くなると大きくなる。また，管中心付近の粘 度は水に比べて非常に大きくなっていることが予測さ れる。

また，(11)式にパラメーターAの值を代入して求めた 流速分布を図 22 に亦寸。四中の各キーは測定值を表わ しており，(11)式は概文妥当な関係式といえる。

さて, $1 \%$ 以下のパルプサスペンションの層流域の流 速分布の推定はできたが，1３\%のパルプサスペン ションの層流域のモデリングは残念ながら現時点では できていない。しかし，1\%以下のパルプサスペンショ ンの埸合から推して，条半径位置においてその位置の パルプサスペンションの濃度に対応したビンガム流体 の集まりと考えて推走することが可能ではないかと思 われるが, これは今後の検討問題である。

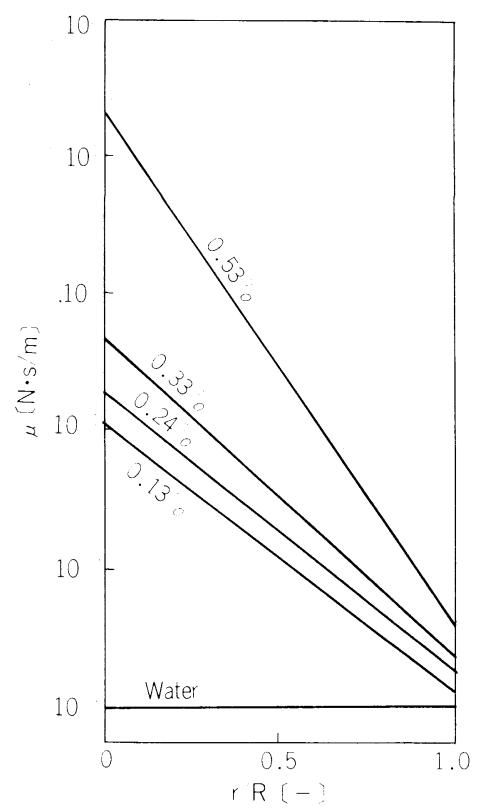

図 $211 \%$ 以トのパルプサスペンションの粘度分布

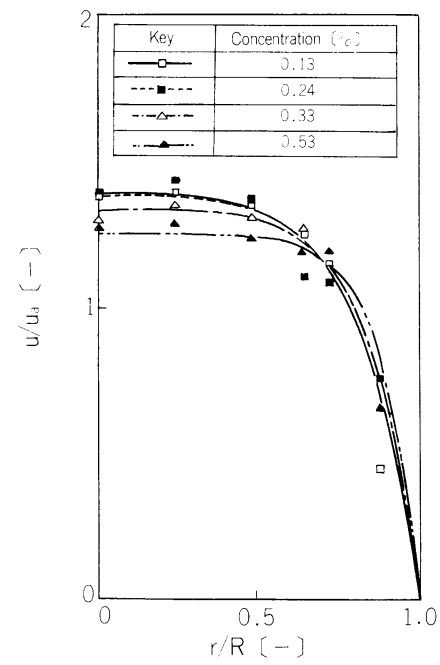

図 22 流動モデルから求めな流速分布と測定値と の比較

\section{むすび}

以上, パルプサスペンションの流動に関して化学工 学的アプローチによる検討結果を示した。

現時点でパルプサスペンションの流動に関して研究 を概観すると, 残念ながら円管内流動の圧力損失の問 題一つにしても，全流動領域を十分にカバーできる一 般的な関係は得られていない状況にあり，また，流動 のメカニズムにいたってはほとんど分かっていない。 これらの問題を解明するには, 今後さらに多くの実騒 的研究が待なれるところであり，また現象に関する観 点の飛躍が要求される。

\section{使用記号}
A : パラメーター
$[-]$
$\mathrm{a}$ ：相対栓半径
$\mathrm{C}$ : パルプ繊維濃度
$[-]$
$\overline{\mathrm{C}}$ : 管断面平均パルプ繊維濃度。
$[\%]$
D：管径 (内徍)
$[\%]$
$\mathrm{f}$ : 管摩擦係数
[m]
$\mathrm{f}^{*}$ : 管摩擦係数
$\mathrm{L}$ : 管軸方向距離
$\mathrm{n}$ : パラメーター
[m]
$\mathrm{Q}$ ：流量
$\mathrm{R}$ ：管半径
$\left[\mathrm{m}^{3} / \mathrm{s}\right]$
$\mathrm{r}$ ：半径位置
[m]
$\mathrm{Re}$ ：レイノルズ数
[m]
$\mathrm{Re}^{*}$ : レイノルズ数
[-]
$[-]$
$\mathrm{u}$ : 流速
$[\mathrm{m} / \mathrm{s}]$ 
$\mathrm{u}_{\mathrm{a}}$ : 管断面平均流速

$\Delta \mathrm{P}:$ 圧力損失

$\alpha: \mathrm{a}$ の関数

$\dot{\gamma}:$ 剪断速度

$\dot{\gamma}_{\mathrm{w}}$ ：管壁における剪断速度

$\mu:$ 粘度

$\mu_{\mathrm{a}}:$ 見かけ粘度

$\mu_{\mathrm{B}}$ : ビンガム流体の粘度

$\mu_{\mathrm{w}}$ ：管壁における粘度

そ：運動エネルギーの補正係数

$\rho:$ 密度

$\tau:$ 剪断応力

$\tau_{\mathrm{B}}$ : ビンガム流体の降伏応力

$\tau_{\mathrm{w}}:$ 管壁における剪断応力
小川浩平，吉川史郎，小川博久 $[\mathrm{m} / \mathrm{s}]$

$\left[\mathrm{N} / \mathrm{m}^{2}\right]$

$[-]$

$[1 / \mathrm{s}]$

$[1 / \mathrm{s}]$

$[\mathrm{kg} /(\mathrm{m} \cdot \mathrm{s})]$

$[\mathrm{kg} /(\mathrm{m} \cdot \mathrm{s})]$

$[\mathrm{kg} /(\mathrm{m} \cdot \mathrm{s})]$

$[\mathrm{kg} /(\mathrm{m} \cdot \mathrm{s})]$

$[-]$

$\left[\mathrm{kg} / \mathrm{m}^{3}\right]$

$\left[\mathrm{N} / \mathrm{m}^{2}\right]$

$\left[\mathrm{N} / \mathrm{m}^{2}\right]$

$\left[\mathrm{N} / \mathrm{m}^{2}\right]$

\section{参考文献}

1) W. Brecht and H. Heller : Tappi p 14 A-48 A, 9, vol. 33 (1950)

2) G. G. Duffy, A. L. Titchener, P. F. W Lee and K.
Moller : Appita p 363-370, 5, vol. 29 (1976)

3) James W. Daily and George Bugliarello: Tappi p 497-512, 7, vol. 44 (1961)

4) B. G. Norman, K. Moller, R. Ek and G. G. Duffy: "Hydrodynamics of Papermaking Fibers in Water Suspension” : Paper Technology Department, Swedish Forest Products Research Laboratory, Stockholm, Sweden

5）伊藤：“化学技術者のための流体工学”：科学技術 社

6) Kohei Ogawa,. Shiro Yoshikawa, Akira Suguro, Jun Ikeda and Hirohisa Ogawa: Journal of Chemical Engineering of Japan p 1-6, 1, vol. 23 (1990)

7) Kohei Ogawa, Shiro Yoshikawa, Jun Ikeda and Hirohisa Ogawa: Tappi Journal p 217-221, 4, vol. 73 (1990)

8）梶内, 薄井: “分散系のレオロジーと分散化技 術”：信山社サイテック 